IRJMS

1,1

82

Received 5 December 2021 Revised 27 December 2021 Accepted 7 January 2022

\section{Case Study Telecom industry and competitive landscape in India: will MTNL and BSNL successfully recover?}

\author{
Rohit Kumar and Pallav Bose \\ Strategic Management, Indian Institute of Management Ranchi, Ranchi, India
}

\begin{abstract}
Purpose - This case study aims to analyse the different factors that cause a decline in an organisation's performance. It projects data for the prospective case readers to explore the possible approaches for the Chairman-cum-Managing Director (CMD) of Mahanagar Telephone Nigam Limited (MTNL) and Bharat Sanchar Nigam Limited (BSNL) to turnaround both the organisations. Furthermore, the case compels the readers to study the Indian Telecom industry to analyse the competitive behaviour and the consequent actions necessary to survive and thrive amongst their peers. From the theoretical perspective, the case emphasises the recent change observed in the Telecom industry regarding the transition from value-chain to value-network. Design/methodology/approach - The authors collected the case facts and data for the case study from secondary sources like the latest news articles, the CRISIL database, company annual statements, company press releases and government regulatory body web portals.

Findings - The case study has identified the issues pertinent in the public sector companies in India, especially in the telecom sector, concerning leadership, pending government financial commitments and a slow-moving attitude towards taking action.

Originality/value - The case study highlights the management problems faced by the CMD of the two public sector telecom companies i.e. BSNL and MTNL.
\end{abstract}

Keywords Indian telecom industry, Competitive landscape, Turnaround strategy, Value chain,

Value network

Paper type Case study

\title{
Introduction
}

On March 18, 2021, the Government of India (GoI) extended PK Purwar's additional charge for 6 months as the Chairman-cum-Managing Director (CMD) of Mahanagar Telephone Nigam Limited (MTNL) (Economic Times, 2021b). MTNL has its roots in Bombay Telephone, founded in 1882 (MTNL, 2022) and now in 2021, is on the verge of closure (Tripathi, 2019). Purwar, a 1990batch of "Indian Post \& Telecommunication Accounts and Finance Service" (IP\&TAFS) with over 30 years of experience, also manages Bharat Sanchar Nigam Limited (BSNL) as CMD. He now has an uphill task to design and develop the revival strategy for both the telecom companies in the wake of high competition from private players like Reliance Jio and Bharti Airtel.

In 2021, India is gearing up for the adoption of 5G technology, with the government announcing the technology spectrum auction (Ahmed, 2021a), and Purwar has to oversee both companies' smooth transition to $5 \mathrm{G}$ technology. But before getting into the $5 \mathrm{G}$ space, Purwar has to address multiple challenges, from the crunch of skilled staff due to recent voluntary retirement adopted by 90,000 employees (Jain, 2020a) to losing customers to the

IIM Ranchi journal of management

(C) Rohit Kumar and Pallav Bose. Published in IIM Ranchi Journal of Management Studies. Published by Emerald Publishing Limited. This article is published under the Creative Commons Attribution (CC BY 4.0) licence. Anyone may reproduce, distribute, translate and create derivative works of this article (for both commercial and non-commercial purposes), subject to full attribution to the original publication and authors. The full terms of this licence may be seen at http://creativecommons.org/licences/by/4.0/ legalcode. 
competition, fund shortage (Abbas, 2019), wage delays, dragged vendor payments and similar strategic issues. In October 2019, GoI announced to back up MTNL and BSNL with an INR 70,000 crore (Doval, 2019) (960 million USD) revival strategy and to merge (The Hindu BusinessLine, 2019) both the telecoms. However, in March 2021, the decision on the merger was kept on hold (The Hindu, 2021). With this uncertainty, Purwar is expected to devise a revival strategy to survive both the telecom companies in India. Also, will the transition from a value chain to a value network work in the case of MTNL and BSNL? What should Purwar do to achieve this strategic transition?

\section{About BSNL and MTNL}

BSNL and MTNL are the oldest telecom service provider in the country and had seen it all, from the introduction of landlines to the present-day $4 \mathrm{G}$ hi-tech services. Starting 2021, they are expected to see through a significant transition in the telecom industry to launch $5 \mathrm{G}$ technology-enabled services.

MTNL

The history of MTNL dates back to the pre-independence era of 1882 when Bombay Telephone started its operations. It was only on April 1, 1986, when the GoI set up MTNL to upgrade telecom services quality, introduce newer services and expand the network in the country's major metropolises - Delhi and Mumbai. MTNL is headquartered in New Delhi and without any listing in any of the country's major stock exchanges. MTNL currently holds $14.48 \%$ of the wireline market share and $0.28 \%$ of the wireless market share in India. The cumulative subscriber base of MTNL stands at 6.23 million as of February 2021 (Telecom Regulatory Authority of India, 2021a). The revenue of MTNL dropped from 300 million USD in FY19 to 270 million USD in FY20. Currently, customers choose from various services provided by MTNL, including basic telephone, 2G \& 3G GSM, FTTH, ISDN, Broadband, leased circuits, IN service, Wi-Fi hot spots and data centres.

Since MTNL is a public sector enterprise, the organisation is awarded "Navaratna" (Department of Public Enterprises, 2020) status by the GoI. MTNL took the first significant step after its setup was the large-scale introduction of the push-button telephone to make dialling easier. Subsequently, before the liberalisation of the telecom sector, MTNL had already introduced Phone Plus service in 1988 and Voice Mail service in 1992. The decade post-liberalisation saw MTNL introducing Internet services in 1995, ISDN service in 1996 and Wireless in Local Loop service in 1997. In 2000, MTNL endorsed a new wholly owned subsidiary, Millennium Telecom Limited (MTL). 2001 was critical for MTNL since it was jumping on to the business of mobile telecommunication. It launched GSM cellular service in India. The same year saw MTNL progressing with a joint venture in Nepal under the name United Telecom Ltd. Year 2003 saw MTNL introducing CDMA technology and a pilot project for providing broadband Internet services. In the same year, a wholly owned subsidiary of MTNL, under Mahanagar Telephone Mauritius Ltd, was launched in Mauritius. By 2004, MTNL had expanded its GSM and CDMA capacity by a total of 1.6 million lines. It also slashed its costly STD/ISD service rates by $60 \%$. In 2005 MTNL officially launched its broadband Internet services and in 2006, launched IPTV services. In the same year, it started procuring WCDMA 3G service equipment. Subsequently, in 2008 and 2011, MTNL successfully launched 3G mobile services and FTTH services in India (see Table 1).

MTNL has two wholly owned subsidiaries, one in India, incorporated in 2000 as MTL, another one in Mauritius, incorporated in 2004 as Mahanagar Telephone Mauritius Limited (MTML). MTNL has two joint ventures, one with STPI (Software Technology Parks of India), incorporated in 2006 as MTNL STPI IT Services Ltd. (MSITS), with MTNL having 50\%

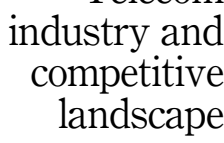

83 


\section{$\underset{1,1}{\operatorname{IRJMS}}$}

1986 Mahanagar Telephones Nigam Limited was established

1987 Push-button telephones were introduced and it made dialling more convenient

1988 Phone Plus services increased benefits for telephone customers

1992 Introduction of Voice Mail Service

1995 Introduction of Internet in India (Delhi)

1996 Launch of ISDN services

$84 \quad 1997$ Launch of Wireless in Local loop

1999 Introduction of Internet based services

2000 Millennium Telecom Limited is established as a fully owned subsidiary of MTNL

2001 Dolphin, a GSM cellular phone service that was launched. WLL mobile services were launched under the Garuda brand. United telecom ltd., which is a MTNL Joint venture in Nepal, started providing WLLbased services in Nepal. MTNL got listed on the New York Stock Exchange (NYSE). Internet express services based on the CLI (command-line interface) were now available

2002 Under the Trump brand, pre-paid GSM mobile services were launched. MTNL Mail, a brand of email on PSTN lines, was introduced

2003 Garuda 1-x was the first CDMA 1x 2000 technology to be introduced. A pilot project for ADSL-based Broadband services was launched. Virtual Phone services were introduced. Mahanagar Telephone Mauritius Ltd. In Mauritius was awarded the second operator licence

2004 GSM and CDMA capacity increased by 800,000 lines each (for a total of 1.6 million lines) while STD/ISD prices were reduced by nearly $60 \%$. In Mauritius, MTNL subsidiary MTML has been granted a licence to operate fixed, mobile and ILD services. Wi-Fi and digital certification services were launched. CETTM, a cutting-edge training facility, was inaugurated

2005 In terms of GSM subscriber additions, became the market leader. TRI BAND, a broadband service brand, was launched. A tender for one million $3 \mathrm{G}$ GSM lines was issued

2006 In November 2006, the IPTV service was launched. The deployment of WiMAX begun. The purchase of equipment for the WCDMA $3 \mathrm{G}$ service started, and the pilot launch of the Wi MAX service begun

Table 1. Important milestones of MTNL

2008 For the first time in India, 3G mobile service was launched

2011 FTTH services were launched

Source(s): Compiled by the authors from company website (history)

equity. The second one with Videsh Sanchar Nigam Limited (VSNL), Telecom Consultants India Limited (TCIL) and NVPL (Nepal Ventures Private Limited, a Nepalese Company) incorporated in 2001, as United Telecom Limited (UTL), with MTNL having $26.68 \%$ equity.

BSNL

The history of BSNL dates back to the British era and is the country's oldest communication provider. It started the first telegraph line back in 1851 as part of the Postal and Telegraph Department in the British Period (BSNLTeleServices, 2021). BSNL was incorporated in the year 2000 as an Indian telecommunications service provider owned by the Department of Telecommunications (DoT), Ministry of Communications, GoI, headquartered in New Delhi. BSNL offered landline services, and by 2002, it launched GSM-based mobile services popularly known as "CellOne" across all its telecom circles in India (The Times of India, 2002). In 2005, BSNL launched its broadband Internet services under the name "Data One" in over 200 cities in India (The Financial Express, 2015). Furthermore, in 2009 it launched 3G mobile services across 11 cities (The Economic Times, 2009). In 2013, BSNL launched multi-protocol label switching (MPLS) technology to provide IP VPN services, thus providing corporate networking services (Pandey, 2004). It claimed that this service would reduce 50\% cost in comparison to the conventional leased line network. In 2018, BSNL launched a VOIP based phone service through an app under the name of "BSNL WINGS", offering free audio/video calling services (Dinakaran, 2018). BSNL launched fibre-to-the-home (FTTH) broadband service in 2020 to compete with JioFiber, Airtel and Tata Sky broadband services (BSNL Launches New Bharat Fiber, 2020). In 2019, BSNL launched its 4G LTE services with the 
plans of expanding them to all the telecom circles (India Today, 2019). BSNL introduced first in the world satellite-based IoT network in India in a partnership with Skylo (Press Information Bureau, 2020). The motive was to connect with machines, industrial IoT devices and sensors in a single network (see Table 2).

As of February 2021, it is the largest provider of wireline telecommunication in the country, with a $33.75 \%$ market share and the fourth-largest wireless service provider with $10.14 \%$ (Telecom Regulatory Authority of India, 2021b). The cumulative subscriber base of BSNL stands at 125 million as of February 2021. The revenue of BSNL dropped from 2.36 billion USD in FY19 to 2.3 billion USD in FY20 (BSNL, 2020).

\section{The telecom industry in India}

India has the world's second-largest telecom network in terms of telephone subscriber base, with a total of 1,187.90 million users registered by the end of February 2021 (Telecom Regulatory Authority of India, 2021b). The number of active wireless telephone connections in India rose from 584.32 million in 2010 to 1157.75 million in 2020 (see Figure 1). The Gross Domestic Product (GDP) contribution of the telecom industry is substantial and is steadily

$\begin{array}{ll}1990 \text { s } & \text { BSNL landline launched } \\ 2000 & \text { BSNL was incorporated by the Government of India } \\ 2002 & \text { Launched mobile services (Cellone) across all BSNL circles } \\ 2005 & \text { Launched broadband services } \\ 2009 & \text { Launched 3G services } \\ 2013 & \text { Launched multi-protocol label switching (MPLS) technology to offer IP VPN services } \\ 2018 & \text { BSNL Wing Services in } 22 \text { telecom circles launched } \\ 2020 & \text { Bharat Fiber (FTT) launched } \\ 2019 & \text { Launched 4G services } \\ 2020 & \text { Launched satellite-based Internet of things (IoT) device service }\end{array}$

Telecom industry and competitive landscape

Source(s): Compiled by the author from the company website and news articles

Table 2. Important milestones of BSNL

\section{Wireless Telephone Connections (million)}

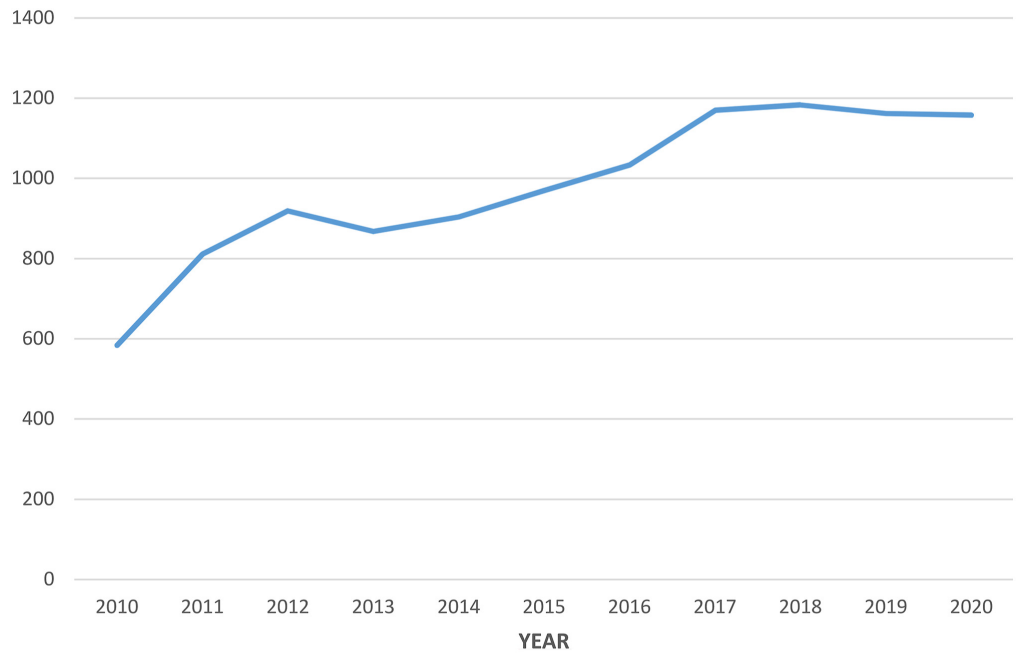

Source(s): Authors' own creation from TRAI's annual report

Figure 1.

Wireless Telephone connections in India from 2010 to 2020 
IRJMS 1,1

\section{6}

growing. Due to the booming telecom industry, India is witnessing an explosion in digital activities, which has aided the government to rely heavily on digital solutions to longstanding problems (GSMA, 2017). The gross revenue from the telecom sector has touched Rs. 691.1 billion (USD 9.35 billion) in FY21, the 3rd quarter (IBEF, 2021). The industry is anticipating the addition of 500 million Internet users due to the declining cost of data and mobile phone penetration over the next five years.

Indian Telecom sector - pre-liberalisation and post-liberalisation

The liberalisation policies embraced by the GoI in 1991 brought a paradigm shift in the Indian telecom sector. The sector saw a transition from a governmental monopolistic regime to that of an openly competitive environment. Before liberalisation, the telecom sector exhibited poor teledensity, high tariffs, low quality of services and poor customer satisfaction (Gupta, 2015). Three crucial policy initiatives were introduced to curb these challenges, which paved the way for exponential growth in the telecom sector. The first policy was the National Telecom Policy, 1994 (NTP94). It highlighted the poor teledensity of the country at 0.8 per hundred people contrasting to the average world teledensity of 10 per hundred people (National Telecom Policy, 1994). The policy introduced the establishment of a duopoly regime concerning two operators in the four metropolitan cities and each of the 18 telecom circles Government of India (2021). Although the duopoly regime ensured the continuance of the government dominance in the telecom sector, this policy ensured protecting consumer interest and fair competition. It emphasised establishing a regulatory body and compelled the government to enact the Telecom Regulatory Authority of India (TRAI) Act 1997. The third policy implementation was the implementation of the New Telecom Policy 1999 (NTP99) (Department of Telecommunications, 1999). It was brought in to handle the inadequacies of NTP94 and further liberalise the scope of the telecom services. Furthermore, it approved interconnection, shared resources among operators and replaced duopoly by the free entry of private players in the telecom sector.

\section{Telecom customers and their increasing demands}

The ever-increasing customer base has been attributed to the inflow of enormous investment in the form of FDI in this sector. The FDI in the telecom sector has been recorded to a total of USD 37.62 billion, which is the third-highest in terms of percentage of total FDI inflows Government of India (2020). The number of mobile phones sold in India rose from 150.33 million in 2010 to 241.95 million in 2020 (see Figure 2). Also, the first quarter of FY21 saw a $16.6 \%$ y-o-y increase in customer spending on telecom services, of which $75 \%$ was on data services despite a lack of offline recharges during the COVID-19 restrictions. Scholars have identified that network and sales service quality is amongst the primary attributes of the existing and new prospective customers (Ranaweera and Neely, 2003). With the advent of 4G technologies, the last decade has changed the perspective of a typical telecom customer demanding simple voice-based service to that of content-driven services like video calling, OTT platforms, mobile banking, to name a few.

A recent study suggests that the customer is now more informed and invested in gathering the service and product details (Devadatta, 2017). The customers are more impressed by service providers, which empower them with exposure to maximum promotions and information, giving them the flexibility and ease to customise their services. Thus, the telecom sector is looking into the phenomenon of "customer-managed services". This way of empowering the customers is taking the customers' experience to a new level of satisfaction while helping the telecom sector grow further by increased consumption of services, resource utilisation and improved profit margin. 
Mobile phone sales (in million)

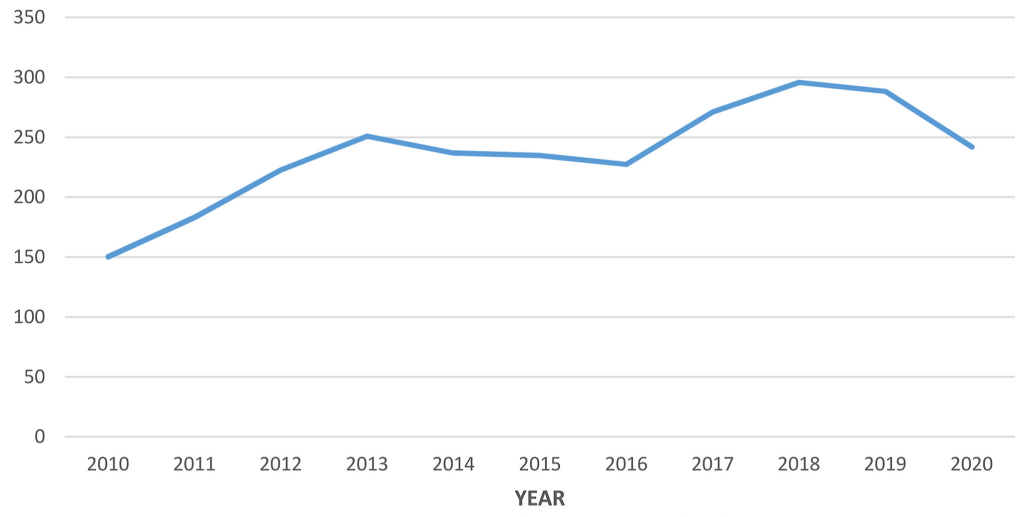

Source(s): Authors' own creation with the data compiled from 'Euromonitor Passport' database
Telecom industry and competitive landscape
Figure 2. Mobile phone sales in India from 2010 to 2020

\section{Telecom value chain (upstream and downstream activities)}

The telecom value chain can be divided into two broad categories - first, the services and applications related to the content and second, network architecture and access devices (Sabat, 2002) (see Figure 3). There are several crucial players involved in the value chain with specific roles. Content providers primarily create content that is to be accessed by the subscribers through their devices. Then there are service providers who provide the necessary network, facilitating the subscribers to access the content. Next, the network

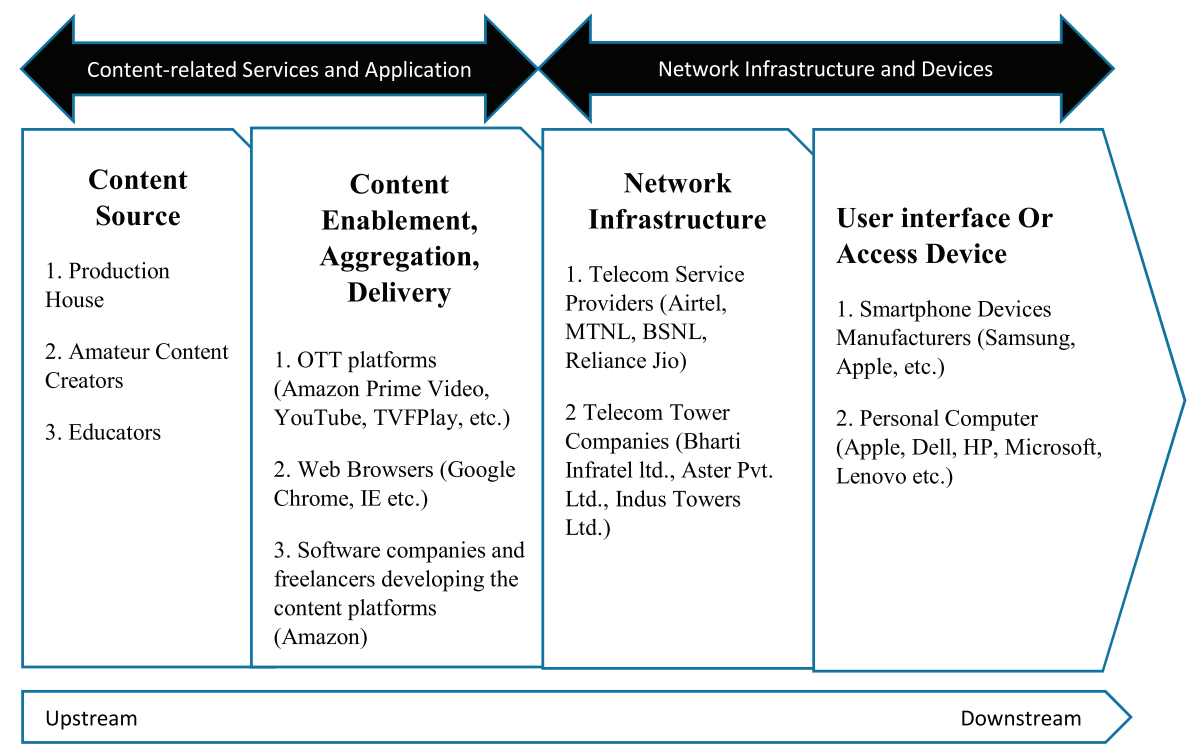

Source(s): Adopted from Sabat (2002)

Figure 3.

The mobile wireless value chain 
IRJMS

1,1 infrastructure vendors are facilitating the required equipment to the network service providers. Finally, the mobile device vendors are providing necessary equipment to the final subscriber to access the content.

The first segment of the value chain related to content is divided into two categories. First, the content providers or content sources focus on the activities occurring in the upstream part of the telecom value chain. The second category constitutes the content enablers, i.e. OTT platforms, portals, system integrators, browsers and middleware solutions. These activities in this category mark the beginning of the downstream part of the telecom value chain.

Similarly, the second segment of the value chain is related to the network is further divided into two categories. First, the network infrastructure enables the secure transmission of the contents reliably to the subscribers to download and consume in their devices. This category of network infrastructure is further divided into core network equipment (router, node, servers and storage), radio access components (base stations, wireless modems, radios and circuits), hosting services, wireless LAN hardware, network operators and wireless service providers, and towers. The network operators and wireless service providers provision and manage the wireless network. The second category in the network segment is related to the user interfaces or access devices. The primary function of these devices is to provide access to the content consumable in audio-visual form. The basic access devices are handsets and personal computers. These devices need a basic display - a screen or audio output device speaker and a browser. This segment signifies the core downstream activities involved in the telecom value chain.

\section{From value chain to value network}

The value chain perspective has limitations in terms of restricting the value creation to a single end product profiting a single organisation with a restriction on utilising the full potential of the connected players in the chain (Peppard and Rylander, 2006). It was suitable for a physical product-based system like the wireline telephony. However, with the evolution of the end products, i.e. digitisation from the suppliers end to the final consumer deliverables, there is a need to shift from the value chain to the value network. Value network mainly deals with creating maximum value by combining values from the different economic actors in the system, i.e. suppliers, competitors and customers. The value networks consist of autonomous elements linked by service level agreement (SLA). Also, the position of the firm in these networks decides its performance and competitive advantage.

This can be seen in the case of the private telecom operators like Reliance Jio's collaboration with "Disney + Hostar VIP", Vodafone-Idea's collaboration with "Zee5" and Airtel's collaboration with the "Amazon Prime", "Disney + Hostar VIP" and "Zee5", with the telecom operators' prepaid mobile recharge plans. In contrast, until July 2021, neither BSNL nor MTNL have collaborated with the OTT platforms for their prepaid mobile recharge plans, although OTT platforms are assessable through the broadband plan subscriptions of BSNL.

\section{Competitors to watch}

Currently, BSNL stands at the number one position for having the highest market share (subscriber base) in the wireline telecommunication services, whereas it has fourth in the wireless telecommunication sector. In the wireless sector, BSNL is behind Reliance Jio, Bharti Airtel and Vodafone-Idea (see Tables 3 and 4).

\section{Reliance Jio}

The services of Jio went public in September 2016, is currently India's most prominent and world's third-largest mobile network provider, with a total customer base of 426.2 million as 
of March 31, 2021 (Reliance Industries Limit, 2021). It operates only on a 4G network in the 22 telecom circles and does not offer $2 \mathrm{G}$ or $3 \mathrm{G}$ services as fellow incumbent telecom service providers do. The company registered a $28.9 \%$ growth in data traffic in FY21, which stood at 62.5 billion GB (gigabyte). Jio introduced JioFiber, a fiber-to-the-home service, on its third anniversary in September 2019, offering a bundled set of services, ranging from television, telephone to broadband services (Mukherjee, 2019).

When most other telecom operators of the country are reporting losses, Jio, in the JanuaryMarch quarter of 2021, reported $47.5 \%$ growth in consolidated net profit and an $18.9 \%$ increase in revenue y-o-y. Similarly, the data and voice traffic saw a rise of 26.7 and $17.9 \%$ y-o-y, respectively (Shantanu, 2021). In his statement, Reliance Industries Chairman and Managing Director Mukesh Ambani said -

Jio has a highly engaged 426 million customer base and remains committed to enhancing digital experiences not only for our existing customers but for all individuals, households, and enterprises across the country. With its path defining partnerships over the last couple of years, Jio will continue to strive towards making India a premier digital society. (The Statesman, 2021)

\section{Bharti Airtel}

Airtel is an Indian MNC telecom service provider with service stretching to 18 countries, providing $2 \mathrm{G}$ and $4 \mathrm{G}$ services. It is the second-largest mobile network operator in India and the world, with a worldwide customer base standing at 471 million, of which 350 million customers are from India, as reported till March 31, 2021 (Airtel, 2021). In Q4 of FY21, Airtel witnessed the highest number $(2,74,000)$ of customer addition. Furthermore, Airtel had successfully strengthened its network by adding a $355.45 \mathrm{MHz}$ spectrum in its bandwidth. In 2020, Airtel was named as the most valuable Indian telecom brand and the fourth most valuable Indian brand by BrandZ Top 75 most valuable Indian brands (Best Media Info, 2020).

Recently Airtel launched a brand campaign highlighting the superior customer preference and differentiated services for its network in comparison to its competitors (The Financial Express, 2021a). In his statement Bharti Airtel Chief Marketing Officer, Shashwat Sharma said -

We have one and only one guiding principle - customer obsession, and it is gratifying to see customers reward Airtel for constantly listening to them and innovating to serve them even better, especially at a time when the pandemic has redefined the normal. Today, Airtel has the highest number of active mobile subscribers in India, and more importantly, we believe we are leading in the hearts of customer (Economic Times, 2021a)

\section{Vodafone-Idea (VI)}

$\mathrm{VI}$ is an Indian telecom service company providing $2 \mathrm{G}$ and $4 \mathrm{G}$ services with a consolidated subscriber base of 269.8 million as reported till Q3 of FY21 (Vodafone-Idea, 2021a). It has the

\begin{tabular}{|c|c|c|c|c|c|c|}
\hline & Total & BSNL & MTNL & $\begin{array}{l}\text { Reliance } \\
\text { Jio }\end{array}$ & $\begin{array}{l}\text { Bharti } \\
\text { Airtel }\end{array}$ & $\begin{array}{l}\text { Vodafone- } \\
\text { Idea }\end{array}$ \\
\hline $\begin{array}{l}\text { Market Share - } \\
\text { Wireless }\end{array}$ & $\begin{array}{l}\text { 1,167.71 million } \\
\text { customers }\end{array}$ & 10.14 & 0.28 & 35.54 & 29.83 & 24.2 \\
\hline $\begin{array}{l}\text { Market Share - } \\
\text { Wireline }\end{array}$ & $\begin{array}{l}20.19 \text { million } \\
\text { customers }\end{array}$ & 33.75 & 14.48 & 15.6 & 23.3 & 2.58 \\
\hline $\begin{array}{l}\text { Employee Strength } \\
\text { ARPU }\end{array}$ & & $\begin{array}{r}65,296 \\
69\end{array}$ & $\begin{array}{r}3,899 \\
69\end{array}$ & $\begin{array}{r}17,500 \\
164\end{array}$ & $\begin{array}{r}9,958 \\
177\end{array}$ & $\begin{array}{r}11,486 \\
141\end{array}$ \\
\hline
\end{tabular}

Source(s): Compiled by the authors from Company's Annual Reports

Telecom industry and competitive landscape 
IRJMS

1,1

third-largest mobile telecommunication network in India and the seventh-largest in the world. VI was formed in August 2018 from the merger of Vodafone India and Idea Cellular. It got its brand identity from the integration of the separate brands of Vodafone and Idea into a unified brand in September 2020 (The Indian Express, 2020). Furthermore, VI became the fastest Indian telecom after passing the speed test certified by Ookla, with a continued streak for three consecutive quarters till March 2021.

Furthermore, VI became the first telecom operator of the country to provide Managed Services for Enterprise customers, having superior features of high-end security, resilience, flexibility and customisation (Vodafone-Idea, 2021b). Enterprise customers from BPOs/ KPOs, IT/ITES, BFSI and the telemarketing sector, will get superior telecom services enhancing their telecom infrastructure optimisation and monitoring. The Chief Enterprise Business Officer of VI Abhijit Kishore said

With the introduction of VI Managed SIP service, VI is now in a position to be a single point facilitator of comprehensive fixed telephony solutions that enable businesses to gain better control of their overall voice infrastructure and the ability to garner meaningful insights on voice performance for their clients/ internal stakeholders. I am confident that this significant addition to our basket of best in class, holistic communications solutions for Enterprises, will help our customer organisations transform the way they communicate with their customers (Ahmed, 2021b)

\section{Telecom player's death due to competition}

Over the last three years, the competition in the Indian telecom industry has forced some of the players to shut their shops. Companies forced to either file for bankruptcy, or sell their businesses, were Reliance Communication, Tata Teleservices - Tata Docomo and Aircel.

\section{Reliance communication}

Reliance Communication, also known as RCOM, founded in July 2002 (Reliance Infocomm Limited), was an Indian Telecom service provider that offered $2 \mathrm{G}$ and $3 \mathrm{G}$ services. It was the pioneer of nationwide CDMA2000 service introduced in 2002 (Ganapati, 2002). The company was forced to shut down in 2019, and it filed for bankruptcy due to its failure to repay debt (Thomson Reuters, 2019).

$\mathrm{RCOM}$ had once disrupted the Indian telecom market with the introduction of free incoming calls in Rs. 500 (USD \$6.72) and a single outgoing rate of Rs. 1 per minute anywhere in India (Jain, 2020b). It invested heavily in GSM services and ended up having colossal debt. Furthermore, the Ambani brothers scraped down the non-compete agreements between them, which allowed Mukesh Ambani to enter the telecom sector with the acquisition of Infotel Broadband in 2010 (The Economic Times, 2010). In 2013 RCOM attempted to monetise its tower infrastructure by sharing it with Reliance Jio, but it failed to provide any relief to the falling stock price for the company (The Economic Times, 2013). The company decided to merge with Aircel in 2016 to reduce its increasing debt burden, although it also failed due to legal and regulatory uncertainty (NDTV Profit, 2017). In 2018 at the Reliance Communication annual meeting Anil Ambani, the founder of RCOM said

We have decided we will not proceed in this sector. Many other companies have taken a similar call. This is very much the writing on the wall (Arun, 2019)

Ultimately in 2019, after many unsuccessful attempts of revival, RCOM filed for bankruptcy.

\section{Tata Teleservices - Tata Docomo}

A subsidiary of Tata Group, Tata Teleservices Limited (TTSL) was the mobile network division of the group founded in 1996. Tata Docomo was the wholly owned subsidiary of 
TTSL. These companies were burdened by a load of debt and consistent losses. In November 2017, the companies were sold to Bharti Airtel with the transition of the existing customers to the Airtel mobile network by July 2019 (Airtel, 2017).

The company made a series of strategic mistakes, which led to the company's fall. It chose CDMA, a costly service for the bottom of the pyramid customers (Pratap, 2018). It ultimately forced the company to bear the subsidy cost leading to poor financials. Also, they did not invest much in marketing for CDMA service benefits when the whole world favoured GSM services. The founder of technology research firm Jayanth Kolla said

They (Tatas) chose a costlier and better-optimised technology and made it a poor man's technology in India. So, they had to pay out bigger subsidies, leading to poor financials. That was a strategic mistake in the market, (Airtel, 2017)

Next, the company decided to shift to GSM technology by going for a tie-up with NTT DoCoMo of Japan in 2008. DoCoMo invested USD 2.2 billion in the company, but it was a futile exercise since TTSL could not use the opportunity to revive the company leading to the exit of DoCoMo from the joint venture (Aulakh, 2017). The main reason for missing the opportunity was the company's culture of slow decision making. Kolla said

They were not the fastest moving or decision-making company in the sector. The culture of longdrawn processes that work for older industry companies in the group spilled over to TTSL. When the industry was moving with faster decision making, they did not react that much. (Airtel, 2017)

\section{Aircel}

Aircel Limited was an Indian telecommunication service provider founded in 1999, providing $2 \mathrm{G}$ and $3 \mathrm{G}$ services. It was once the market leader in Tamil Nadu, where it started its operation. Aircel was shut down in February 2018 due to its unprofitable business, enormous debt (Kurup, 2018). Aircel statement said

Intense competition following the disruptive entry of a new player, legal and regulatory challenges, high level of unsustainable debt and increased losses had together caused significant negative business and reputational impact on the company (India Today, 2018)

Furthermore, the company, in the last attempt, tried to merge its wireless business with Reliance Communication which turned out to be a futile attempt at the last minute (Business Today, 2018). Aircel statement said

Post detailed discussions with the financial lenders and shareholders; the company could not reach consensus regarding restructuring its debt and funding. Despite these discussions and the invoking of a strategic debt restructuring scheme in January 2018 ... no agreement could be reached (India Today, 2018)

\section{MTNL-BSNL merger: decision pending}

Rationale and government support

At present, both BSNL and MTNL are ailing due to their cash crunch, declining customer base, fierce cost-cutting competition from private players rolling out superior $4 \mathrm{G}$ services PAN India (Tripathi, 2019). To revive BSNL and MTNL, the government approved a fourstep process in November 2019, covering a capital investment of INR 70,000 crores (USD 960 million), merging the two telecoms. It was the third attempt to merge the companies. The first attempt was made in 2002 when the Telecom Ministry proposed that the merger would bring synergy between the companies. However, the attempt was unsuccessful due to large-scale opposition by the employee union. The second attempt was made in 2015 by the government. 
IRJMS

1,1

It commissioned IIM Bangalore to carry out a feasibility study of the merger and suggest a strategy to merge. However, it never got materialised either. As per the latest revival plan approved by the government, the four steps include - adjustment towards GST, voluntary retirement service (VRS) for employees, capital infusion towards $4 \mathrm{G}$ spectrum purchase and raising capital through sovereign bonds (Lok Sabha, 2021).

However, in the latest turn of events, in January 2021, the government deferred the merger of the two companies citing both companies' high debts as a primary reason. The telecom ministry further noted the merger to be unfeasible and non-beneficial. The telecom ministry has implemented close cooperation and integration between the two companies (Economic Times, 2021c). The situation is indeed food for thought - can two mules make a racehorse? The revival plan lacks any comprehensive plan for the merged entity integrating the organisation's people and works culture. Whereas deferring the merger has posed some serious challenges for Purwar. The revival plan was planning a capital investment of INR 70,000 crores (USD 960 million). Without any such investment for an indefinite period, Purwar needs a plan to manage the enormous debt for both MTNL and BSNL. Furthermore, the $4 \mathrm{G}$ spectrum allocation as part of the revival plan has also been stalled for an unspecified period.

\section{Current challenges}

Leadership challenges

Both BSNL and MTNL have been criticised in the past for their inefficient leadership succession plans. In 2014, Kapil Sibal, the then telecom minister, pointed out the need for mandatory evaluation of the extension of service for the outgoing CMDs (Parbat, 2014). Furthermore, the employee union of BSNL had charged the organisation with failed HR policies due to its inability to pay its salaries (Abbas, 2021). There had also been a case when the image of MTNL got tarnished due to corruption charges against CMD R S P Sinha (The Indian Express, 2009). Sinha was relinquished from the position due to an allegation of fraud in a 2004 tender case. Both the PSU telecom companies are continually witnessing management related challenges in the tenure of Purwar as well. With the implementation of VRS for employees, the organisation is facing issues related to staff shortage at work, leading to a surge in customer complaints and more time in their resolution (Johari, 2020). It further adds up to the list of challenges Purwar is currently facing. Purwar needs to think about whether young employees should be hired at this stage. If new recruitments are made, how will it impact the revival plan of both the telecom companies?

\section{Entry of new players - satellite communication}

Groundbreaking innovators are taking up the level of competition in the recommunication industry to the next level. Recently Elon Musk has ventured into the field of satellite communication. Musk's company SpaceX plans to launch 40,000 satellites under the name of Starlink (News18, 2020). The project shall increase the Internet speed and provide extensive coverage of broadband Internet in remote locations.

\section{The transition from value chain to value network}

Both BSNL and MTNL are deeply invested in the wireline telephony business from the start of their journey. They are acutely embedded in the value chain system of running the business due to a lack of digitisation of their services. Furthermore, both the telecom players are predominantly vertically integrated with minimal third-party involvement as a public sector company. This is evident from the fact that none of the prepaid mobile recharge plans of the telecoms allows the customers to opt for an OTT platform. Now, this is a severe challenge for Purwar. All these drawbacks lead to less usage of data by the customers and 


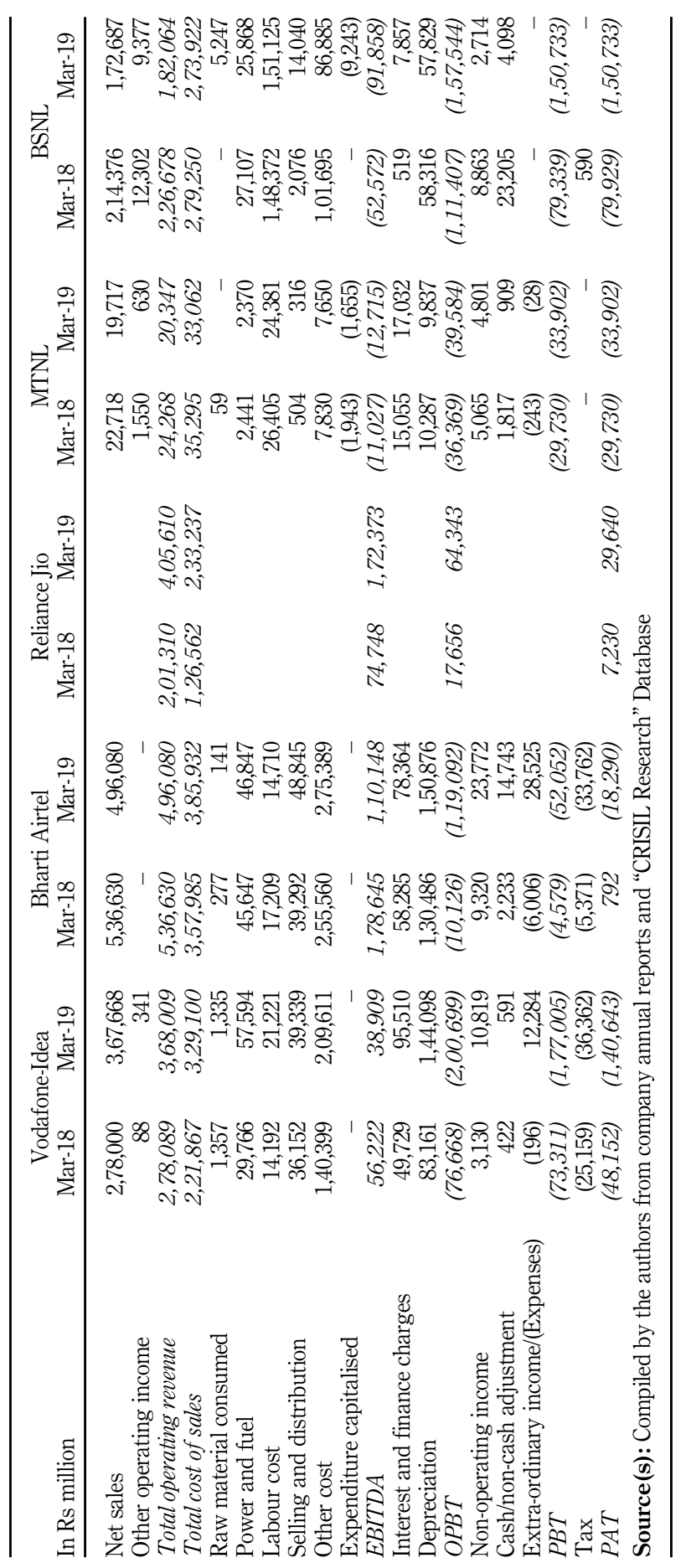

Telecom industry and competitive landscape

93

Table 4.

Telecom players in India: Financial results 2018 Vs 2019 (in INR million) 
IRJMS 1,1

hence fewer chances of enhancing the revenue for the companies. Purwar faces the challenge of shifting the organisation's focus from a value chain-based system to a value network-based system and collaborating with third party firms with an SLA system in place.

\section{The silver lining - 5G spectrum auction}

The Telecom Ministry had announced that both BSNL and MTNL would be allocated 5G spectrum on an administrative basis without any need for the companies to participate in the spectrum auction (The Financial Express, 2021b). The 5G spectrum allocation would be similar to the $4 \mathrm{G}$ spectrum allocation for BSNL in 2021-22. The formal telecom auction for the private players is supposed to occur by the end of 2021 or the beginning of 2022 . Furthermore, the government sees $5 \mathrm{G}$ technologies as a catalyst for bringing in socio-economic reforms in the country (Deloitte India, 2018). This new development can be a game-changer for Purwar since MTNL and BSNL see this opportunity and aspires to penetrate and proliferate into the country's remotest corners. The telecoms believe that the government should give them the best quality of spectrum available, i.e. the $700 \mathrm{MHz}$ frequency band, so that the socio-economic fabric of the country could be transformed (TRAI, 2019). Now Purwar needs to figure out how to bank on this opportunity which shall be causing substantial financial commitments to other private telecom operators but not to BSNL and MTNL as they are public undertakings. The 5G spectrum shall be provided administratively (free of cost) to BSNL and MTNL by the GOI.

\section{Way forward and closing remarks}

With the set of challenges of the dwindling government telecoms and the opportunity of free $5 \mathrm{G}$ spectrum allocation, it is the task of Purwar to analyse the situation and come up with strategic steps to revive MTNL and BSNL. Would Purwar be successful in turnaround the declining phase of MTNL and BSNL, or, for the better sake, the once strategic asset of the government needs to be shut down? What should Purwar do? Should he make a transition attempt of the telecom value chain to a telecom value network? He contemplated the strategies he needed to adopt.

\section{References}

Abbas, M. (2019), "Is Modi’s BSNL, MTNL rescue strategy real? - ET telecom”, The Economic Times", available at: https://telecom.economictimes.indiatimes.com/news/is-modis-bsnl-mtnl-rescuestrategy-real/72366120.

Abbas, M. (2021), "BSNL's HR policy a total disaster: employee group - ET telecom", The Economic Times, available at: https://telecom.economictimes.indiatimes.com/news/bsnls-hr-policy-a-totaldisaster-employee-group/80497914.

Ahmed, Y. (2021), “5G in India, are we there yet?”, India Today, available at: https://www.indiatoday. in/technology/features/story/5g-in-india-are-we-there-yet-1769386-2021-02-15.

Ahmed, Y. (2021), "Vi introduces managed voice service SIP for enterprise customers and businesses", India Today, available at: https:/www.indiatoday.in/technology/news/story/vi-introducesmanaged-voice-service-sip-for-enterprise-customers-and-businesses-1815088-2021-06-15.

Airtel (2017), "Tata teleservices mobile customers to start transitioning to the Airtel network", Airtel, available at: https://www.airtel.in/press-release/11-2017/tata-teleservices-mobile-customersstart-transitioning-to-airtel-network.

Airtel (2021), "Results", available at: https://www.airtel.in/about-bharti/equity/results.

Arun, M.G. (2019), “Anil Ambani: the Fall of a Billionaire”, India Today, available at: https://www. indiatoday.in/magazine/the-big-story/story/20190325-the-fall-of-a-billionaire-1477813-201903-15. 
Aulakh, G. (2017), "Tata sons may soon shut down Tata teleservices, ending a 21-year-old business venture", The Economic Times, available at: https://economictimes.indiatimes.com/news/ company/corporate-trends/tata-sons-may-soon-shut-down-tata-teleservices-ending-a-21-yearold-business-venture/articleshow/60978245.cms?from $=$ mdr.

Best Media Info (2020), "BrandZ top 75: HDFC bank remains the most valuable Indian Brand. The total value of the top 75 brands drops by $6 \%$ ", available at: https://bestmediainfo.com/2020/09/ brandz-top-75-hdfc-bank-remains-the-most-valuable-indian-brand-total-value-of-top-75-brandsdrops-by-6/.

BSNL Launches New Bharat Fiber (2020), "BSNL Launches New Bharat Fiber broadband plans priced from Rs 449”, The Economic Times, available at: https://telecom.economictimes.indiatimes.com/ news/bsnl-launches-new-bharat-fiber-broadband-plans-priced-from-rs-449-report/78380642.

BSNL (2020), "Financial result", available at: https://bsnl.co.in/opencms/bsnl/BSNL/about_us/ financial_result.html.

BSNLTeleServices (2021), "History of BSNL and operational services with new management", available at: https://bsnlteleservices.com/bsnl-history/.

Business Today (2018), "Aircel goes bankrupt, becomes the fourth telecom player to bow out as cutthroat price war takes its toll”, available at: https:/www.businesstoday.in/sectors/telecom/ aircel-bankruptcy-telecom-sector-nclt-numbers-insolvency/story/271714.html.

Deloitte India (2018), “5G: the catalyst to digital revolution in India”, available at: https://www2. deloitte.com/in/en/pages/technology-media-and-telecommunications/articles/the-catalyst-todigital-revolution-in-india.html.

Department of Public Enterprises | Ministry of Finance | Government of India (2020), "List of Maharatna, Navratna and Miniratna CPSEsDepartment of Public Enterprises", available at: https://dpe.gov.in/about-us/divisions/list-maharatna-navratna-and-miniratna-cpses.

Department of Telecommunications | Ministry of Communication | Government of India, available at: https://dot.gov.in/new-telecom-policy-1999.

Devadatta, V. (2017), "Telecom trends: from customer experience management to customer managed experience", Economic Times, [online], available at: https:/telecom.economictimes.indiatimes. $\mathrm{com} /$ tele-talk/telecom-trends-from-customer-experience-management-to-customer-managedexperience/2274 (accessed 18 September 2021).

Dinakaran, R. (2018), "BSNL WINGS - a VOIP based phone service launched", The Hindu Business Line", available at: https://www.thehindubusinessline.com/info-tech/bsnl-launches-voip-basedwings-service/article24703245.ece.

Doval, P. (2019), "BSNL MTNL revival plan: BSNL, MTNL to be merged; centre lines up Rs 70,000 crore revival package", The Times of India, available at: https://timesofindia.indiatimes.com/ business/india-business/bsnl-mtnl-to-be-merged-centre-lines-up-rs-70000-crore-revival-package/ articleshow/71730263.cms.

Economic Times (2021a), "Airtel rolls out a new brand campaign showcasing customers' preference for its network", available at: https://telecom.economictimes.indiatimes.com/news/airtel-rollsout-new-brand-campaign-showcasing-customers-preference-for-its-network/83304398.

Economic Times (2021b), “Government extends Pk Purwar's Mtnl additional charge for six months”, available at: https://telecom.economictimes.indiatimes.com/news/government-extends-pkpurwars-mtnl-additional-charge-for-six-months/81568758.

Economic Times (2021c), "Government defers BSNL-MTNL merger due to financial reasons", [online], available at: https:/telecom.economictimes.indiatimes.com/news/government-defers-bsnl-mtnlmerger-due-to-financial-reasons/81444770 (accessed 14 September 2021).

Ganapati, P. (2002), "Reliance set to revolutionise mobile services", Rediff, available at: https://www. rediff.com/money/2002/dec/27rill.htm.

Government of India (2020), "Department for Promotion of Industry and Internal Trade | MoCI |", available at: https://dipp.gov.in/publications/fdi-statistics. 

${ }_{1,1}^{\text {IRJMS }}$

Government of India (2021), "Department of Telecommunications | Ministry of Communication", available at: https://dot.gov.in/unified-licnse.

GSMA (2017), "Embracing the digital revolution: policies for building the digital economy", available at: https://www.gsma.com/publicpolicy/resources/embracing-the-digital-revolution-policies-forbuilding-the-digital-economy.

Gupta, S. (2015), "Telecommunications at the crossroads in India”, IIMB Management Review, Vol. 27 No. 3, pp. 196-208.

IBEF (2021), “Telecom Industry in India”, available at: https://www.ibef.org/industry/ telecommunications.aspx.

India Today (2018), "Aircel files for bankruptcy; cites intense competition", unsustainable debt, available at: https://www.indiatoday.in/pti-feed/story/aircel-files-for-bankruptcy-cites-intensecompetition-unsustainable-debt-1179539-2018-02-28.

India Today (2019), "BSNL Expands its 4G VoLTE services to more circles, offers bonus data to subscribers upgrading to $4 \mathrm{G}$ SIM", available at: https:/www.indiatoday.in/technology/news/ story/bsnl-expands-its-4g-volte-services-to-more-circles-offers-bonus-data-to-subscribersupgrading-to-4g-sim-1468859-2019-03-02.

Jain, R. (2020a), "Over 450 million users are stuck in Limbo as Vodafone Idea, BSNL and MTNL fight to survive”, Business Insider, available at: https://www.businessinsider.in/business/telecom/ news/450-million-users-stuck-vodafone-idea-bsnl-mtnl/articleshow/74301132.cms.

Jain, R. (2020b), "The rise and fall of Anil Ambani's Reliance communications", Business Insider, available at: https:/www.businessinsider.in/business/news/the-rise-and-fall-of-anil-ambanisreliance-communications/articleshow/74596156.cms.

Johari, A. (2020), “They want to let BSNL die': the rot inside India's government-owned telecom firms", Quartz, available at: https://qz.com/india/1936622/why-indias-bsnl-mtnl-are-losing-outto-firms-like-reliance-jio/.

Kurup, R. (2018), "Aircel is looking at ways to stay afloat", available at: https://www. thehindubusinessline.com/info-tech/aircel-looking-at-ways-to-stay-afloat/article9983369.ece.

Lok Sabha (2021), "Revival of BSNL and MTNL", available at: http://oksabhaph.nic.in/Questions/ QResult15.aspx?qref $=18944 \& 1$ sno $=17$.

MTNL, M. (2022), About Us, [online] Mtnl.in, available at: https:/www.mtnl.in/about-us.html (accessed 15 November 2021).

Mukherjee, A. (2019), "JioFiber now available: here's how you can book a new connection, get free TV and $4 \mathrm{~K}$ set top box", India Today, available at: https://www.indiatoday.in/technology/features/ story/jiofiber-now-available-here-s-how-you-can-book-new-connection-get-free-tv-and-4k-settop-box-1597527-2019-09-10.

National Telecom Policy (1994), “Centre for Internet and Society”, available at: https://cis-india.org/ telecom/resources/national-telecom-policy-1994\#fr1.

NDTV Profit (2017), "Reliance communications-Aircel deal fails: 10 key facts", NDTV, available at: https://www.ndtv.com/business/reliance-communications-aircel-deal-fails-10-key-facts1757393.

News18 (2020), "Elon Musk's ambitious communication project to ring earth with 40,000 satellites", available at: https://www.news18.com/news/buzz/elon-musks-ambitious-communicationproject-to-ring-earth-with-40000-satellites-2890825.html.

Pandey, P. (2004), "BSNL unveils corporate networking service", Business Standard, available at: https://www.business-standard.com/article/companies/bsnl-unveils-corporate-networkingservice-104062901056_1.html.

Parbat, K. (2014), "Handling of succession issues at BSNL, MTNL under fire", The Economic Times, available at: https://economictimes.indiatimes.com/industry/telecom/handling-of-sccessionissues-at-bsnl-mtnl-under-fire/articleshow/31194394.cms?from $=$ mdr. 
Peppard, J. and Rylander, A. (2006), "From value chain to value network: insights for mobile operators", European Management Journal, Vol. 24 Nos 2-3, pp. 128-141.

Pratap, R. (2018), "How Tata Tele lost the telecom war", available at: https://www. thehindubusinessline.com/info-tech/how-tata-tele-lost-the-telecom-war/article9901837.ece.

Press Information Bureau (2020), "BSNL, in Partnership with Skylo, to introduce the worlds' first satellite-based Narrowband-IoT network in India”, available at: https:/pib.gov.in/ Pressreleaseshare.aspx?PRID $=1679714$.

Ranaweera, C. and Neely, A. (2003), "Some moderating effects on the service quality-customer retention link", International Journal of Operations and Production Management, Vol. 23 No. 2, pp. 230-248.

Reliance Industries Limited (2021), "Media releases", available at: https://www.ril.com/MediaReleases. aspx?aliaspath $=\% 2$ FMediaReleases.

Sabat, H.K. (2002), "The evolving mobile wireless value chain and market structure", Telecommunications Policy, Vol. 26 Nos 9-10, pp. 505-535.

Shantanu, S. (2021), "Jio's Q4 net profit grows 48\% to Rs 3,508 crore", India TV, available at: https:// www.indiatvnews.com/business/news-reliance-jio-q4-results-net-profit-grows-48-per-cent-to-rs3508-crore-701669.

Telecom Regulatory Authority of India (2021a), "Telecom subscriptions reports”, available at: https:// www.trai.gov.in/release-publication/reports/telecom-subscriptions-reports.

Telecom Regulatory Authority of India (2021b), “Telecom subscriptions reports”, available at: https:// www.trai.gov.in/release-publication/reports/telecom-subscriptions-reports.

The Economic Times (2009), "BSNL launches 3G pan India", available at: https:/economictimes. indiatimes.com/news/politics-and-nation/bsnl-launches-3g-pan-india/articleshow/4170295.cms? from $=$ mdr.

The Economic Times (2010), "Reliance industries buys 95\% Stake in Infotel broadband for Rs 4,800 Cr", available at: https://economictimes.indiatimes.com/reliance-industries-buys-95-stake-ininfotel-broadband-for-rs-4800-cr/articleshow/6040360.cms?from =mdr.

The Economic Times (2013), "Reliance communication tower deal fails to impress", available at: https://economictimes.indiatimes.com/markets/stocks/news/reliance-communication-tower-dealfails-to-impress/articleshow/20548035.cms?from $=$ mdr.

The Financial Express (2015), "BSNL launches broadband service data one", available at: https:// www.financialexpress.com/archive/bsnl-launches-broadband-service-data-one/124148/.

The Financial Express (2021a), "Airtel rolls out a new brand campaign highlighting customer preference for its network", available at: https:/www.financialexpress.com/brandwagon/airtelrolls-out-new-brand-campaign-highlighting-customer-preference-for-its-network/2266779/.

The Financial Express (2021b), "Spectrum allocation: BSNL, MTNL to get spectrum for $5 \mathrm{G}$ services without participating auction", available at: https://www.financialexpress.com/industry/ spectrum-allocation-bsnl-mtnl-to-get-spectrum-for-5g-services-without-participating-in-auction/ 2220499/.

The Hindu BusinessLine (2019), "Merge MTNL with BSNL", available at: https://www. thehindubusinessline.com/specials/india-file/merge-mtnl-with-bsnl/article28750717.ece.

The Hindu (2021), "Govt. defers merger of BSNL, MTNL”, available at: https://www.thehindu.com/ business/govt-defers-merger-of-bsnl-mtnl/article34038864.ece.

The Indian Express (2009), "HC Asks Govt for the course of action in MTNL CMD case", available at: https://indianexpress.com/article/india/india-others/hc-asks-govt-for-course-of-action-in-mtnlcmd-case/.

The Indian Express (2020), "Vodafone Idea re-brands Itself 'Vi”, available at: https://indianexpress. com/article/business/companies/vodafone-idea-new-brand-identity-vi-key-announcements$6586229 /$.

\section{industry and \\ competitive \\ landscape}



${ }_{1,1}^{\text {IRJMS }}$

The Statesman (2021), "Jio's Q4 net profit grows 48\% to Rs 3,508 crore", available at: https://www. thestatesman.com/business/jios-q4-net-profit-grows-48-rs-3508-crore-1502965530.html.

The Times of India (2002), "BSNL launches cellular services under the brand name "CellOne", available at: https:/timesofindia.indiatimes.com/business/india-business/bsnl-launches-cellularservices-under-brand-name-cellone/articleshow/20955064.cms.

Thomson Reuters (2019), "RCom goes to Bankruptcy court to resolve the Debt Burden", Reuters, available at: https://www.reuters.com/article/rcom-debt/rcom-goes-to-bankruptcy-court-toresolve-debt-burden-idINKCN1PQ4WT? edition-redirect $=$ in.

TRAI (2019), Trai.gov.in. 2019, [online], available at: https://rai.gov.in/sites/default/files/MTNL_ 23072019.pdf (accessed 14 October 2021).

Tripathi, K. (2019), "BSNL: how one of the most profitable PSUs lost to private players reached the verge of closure", The Financial Express, available at: https://www.financialexpress.com/ economy/bsnl-mtnl-news-how-one-of-the-most-profitable-psus-lost-to-private-players-reachedto-the-verge-of-closure/1731092/.

Vodafone-Idea (2021a), "Financial results", available at: https://www.vodafoneidea.com/investors/ results.

Vodafone-Idea (2021b), "Media releases", available at: https:/www.vodafoneidea.com/media/pressreleases.

\begin{abstract}
About the authors
Prof. (Dr) Rohit Kumar is currently working as an Assistant Professor at the Indian Institute of Management, Ranchi, in the Strategic Management area. He has more than 15 years of teaching experience and has published more than 30 research papers and case studies in journals of repute. He is a Fellow of the Insurance Institute of India (FIII), Associate of Chartered Insurance Institute (ACII), UK and Certified- Risk and Insurance Manager (C-RIM). He is also an Accredited Management Teacher (AMT). Rohit Kumar is the corresponding author and can be contacted at: rohit.k@iimranchi.ac.in

Pallav Bose is pursuing her Ph.D. from Indian Institute of Management, Ranchi, in the Strategic Management area. His research interest includes strategic leadership and competitive strategies.
\end{abstract}

For instructions on how to order reprints of this article, please visit our website:

www.emeraldgrouppublishing.com/licensing/reprints.htm

Or contact us for further details: permissions@emeraldinsight.com 